\title{
Ash as an alternative source of raw materials
}

\author{
Olena Svietkina ${ }^{1 *}$, Hanna Tarasova ${ }^{1}$, Olha Netiaha $^{1}$, and Svitlana Lysytska ${ }^{1}$ \\ ${ }^{1}$ National Mining University, Department of Chemistry, 19 Yavornytskoho Ave., 49005 Dnipro, \\ Ukraine
}

\begin{abstract}
The objective of the work is to study the aluminosilicate fractionation from fly ash, physical and mechanical properties of fly ash derived from the Thermal Power Plants (TPP) wastes. Ash, carbon concentrate (unburned carbon), ash concentrate and products of their treatment with reagents were tested by optical methods. The particle morphology of the objects of research was studied with the scanning electron microscope REM-100. The composition of the ash phases was investigated using the X-ray diffractometer DRON-2. A dispersed analysis of the TPP fly ash suggests a conclusion that it is advisable to separate particles of a narrow grain-size class within the range from 40 to $150 \mu \mathrm{m}$ with an ash content of about $33 \%$. The first product may be enriched by flotation method. Such a coal product may be used as a reducing medium in metallurgical processes, agglomeration, etc. The calorific capacitance of the concentrate is about $6000 \mathrm{kcal} / \mathrm{kg}(25000 \mathrm{~kJ} / \mathrm{kg})$.
\end{abstract}

\section{Introduction}

The ash of TPP is formed as a result of coal combustion and, on the one hand, is a source of environmental pollution; but on the other hand, it is a source of raw materials needed for industry.

In Ukraine, thousands of tons of ash, containing a number of useful components, have accumulated in the TPP dump sites. Moreover, more than 10 million tons of fly ash is added annually to the TPP dump sites. Despite the relatively high content of phase constituents with high consumer properties in a number of ashes, it is only possible to attribute them to technogenic minerals by convention, since now there are no available cost effective methods of extracting the useful components. Therefore, ash from thermal power plants is used to a limited extent.

Products of TPP ash separation may be used in various industries: metallurgy, power engineering, chemical industry, in the production of building materials. An important is also the allocation of the ash storage priority for the integrated use of their resources in various sectors of the economy based on a comprehensive comparative analysis of their technological and economic indicators by the integrated assessment method [1].

In metallurgy, attempts are being made to replace the breeze coke with the hightemperature char and anthracite in the process of iron ore concentrate agglomeration. Obviously, a high-carbon flotation concentrate can be used in order to replace partially the

\footnotetext{
*Corresponding author: svetkina.yelena@gmail.com
} 
breeze coke.

In the production of metallized pellets, the fuel additive (breeze coke) makes up 14\% (grain-size $<100$ microns $-70 \%$, ash content $-18.35 \%$, sulfur content $-0.65 \%$ ). Thus, without lowering the quality of metallized pellets, the high-temperature char may be replaced by a flotation concentrate of ash [2].

As a component of pulverized fuel oil compositions for blast furnace processes, it is possible to use low-ash flotation concentrate. In addition, a method was developed for metal siphoning into a mold, which uses a concentrate with carbon content of $35-60 \%$ as a heat-insulating coating. It is important that the use of this material allows abandoning graphite for the same purposes [3].

In the energy sector, the flotation concentrate can be used as a fuel additive to boiler fuel. The use of concentrate can significantly reduce the heat loss from mechanically unburned carbon when burning the coal of rank AS; in addition, the operating parameters of the boiler plant will not deteriorate under the condition of continuous dosing of the concentrate [4].

The method has been developed for sorption of heavy metal cations, which allows capturing them from industrial effluents. In this regard, a concentrate froth of the cleaner flotation is the most effective due to its high carbon content. The cleaner flotation waste with ash content of $40-50 \%$ may be used as a sorbent of organic acids and various petroleum products. An ash-based sorbent, obtained through changes in the boiler furnace temperatures and coarsening the grind of raw materials, is sufficiently effective for the purification of surfactant-containing sewage [5].

Waste of TPP ash flotation is more widely used in the production of building materials than the initial ash. This can be explained by the adjustment of carbon content and granulometric compositions of the ash mineral fraction.

Flotation waste is successfully used in the manufacture of various concretes and concrete mixtures in order to save cement without deterioration in the strength characteristics of the concrete. Moreover, they can be used to obtain special concretes, for example, foam concrete, light-weight and autoclaved cellular concretes. With the addition of ash mineral fraction, the consumption of cement is significantly reduced [6]. In the process of producing bitumen-concrete mixtures, it is recommended to use the product of the TPP ash flotation processing as a mineral powder; the mixture thus obtained is cheaper than that with a limestone mineral powder. It is not inferior in its technological and strength parameters. In the manufacture of wall products, a modified ash of low-reactive coal added to clay may serve as a raw material. The obtained burned bricks have higher strength characteristics than the material with no modified ash admixtures [7].

The promising direction in the use of ash wastes is their processing into various filling agents for building materials. The low density fillers are made by granulating the ash with the subsequent firing of the obtained pellets. Ash, together with sandy loam and a waste admixture from the lead-dressing and processing enterprise, is part of the mixture for flyash aggregate. A method for obtaining artificial aggregate has been proposed, which provides the separation of ash into two classes with subsequent processing of the class containing about $4.5 \%$ of unburned coal residuals.

The TPP ash with high degree of unburned carbon must be subjected to flotation concentration in order to obtain a carbonaceous fraction (concentrate) and a mineral fraction (waste). The unburned particles of coal can be separated by direct flotation using nonpolar and heteropolar surface-activated substances (surfactants) at a low pulp $\mathrm{pH}$ ( $\mathrm{pH}$ $6-8$ and $\mathrm{pH} 3-6.5$ at the first and the second stage, respectively). Several recleanings are used to obtain products of the specified quality. A method has been developed for ash flotation with the use of MK reagent as a collector in the presence of a depressor. The method ensures obtaining conditioned products without recleanings, with $95-98 \%$ carbon yield to the concentrate. The preliminary hydraulic classification of ash into $40 \mu \mathrm{m}$ class 
enhances the efficiency of its separation.

The effect of the raw material grinding on the process of ash flotation was studied. Due to the increased contrast range of the phases being separated, a concentrate with a high content of the combustible fraction has been obtained, with a slight change in the ash content of the waste. The inverse flotation of the TPP ash allows obtaining the products with physical-chemical properties that differ from the properties of the concentrates obtained by direct ash flotation. Hence, the carbon-bearing ash fraction has a high specific surface area, which allows it to be used as an effective sorbent, in contrast to a direct flotation concentrate which has a slightly less effective specific surface area of the particles due to collector adsorption on their surface. The inverse flotation waste manifests clearly expressed hydrophobic properties due to the collector adsorption on the surface of the particles, which allows using it as a hydrophobic filler of polymer composite materials with no additional surface modification [8].

To obtain the raw material for manufacturing heat-insulating materials, fly ash was subjected to the following operations: a preliminary flotation was performed to separate the inorganic and organic parts, followed by activation of the inorganic part by two methods, i.e. chemical and mechanochemical activation. The consumer properties of the raw materials were assessed by studying their phase composition, physical-chemical and physical-mechanical properties, and their compliance with the technical specifications for the further redistribution processes of the products obtained. The objective of the work is aluminosilicate fractionation from fly ash, study of physical and mechanical properties of fly ash derived from the Thermal Power Plants (TPP) wastes.

\section{Methods}

Ash, carbon concentrate (unburned carbon), ash concentrate and products of their treatment with reagents were tested by optical methods. The particle morphology of the objects of research was studied with the scanning electron microscope REM-100. The composition of the ash phases was investigated using the X-ray diffractometer DRON-2.

Mechanochemical activation of the materials was performed in a vertical vibration mill which main advantage is in a shock-vibrating impact upon the material to be destructed [9]. As a rule, mechanical activation happens at the moment of chemical processing in the point of contact between solid substance particles, where chemical processes occur due to the local heat emission, and simultaneous formation of rather high pressures and shear stresses within that area of a crystal.

Shock-vibrating activation of the material makes it possible not only to perform surface shear but also to effect the particles with the penetration of deformation zone into its whole volume. That ensures not only surface activation of the material but also the damage of internal structures of the particles and deeper penetration of active zone; it opens up new opportunities of solid state synthesis - development of the materials having maximum selective conductivity, mechanical strength, chemical and thermal stability

\section{Results and discussion}

Coal ash is formed from all mineral impurities in the coal bands, rock seams of the roof and bottom, which are entrapped in the marketable coal during its mining [10]. The major impurities are clay minerals and quartz, while carbonates, sulfides, iron oxides and other minerals occur in minor amounts. The phase composition of the ash is mainly determined by clay minerals, which are transformed into other aluminosilicates (glass phases, possibly mullite, cristobalite) during high-temperature processing in boiler furnaces. It should be 
taken into account that this is a large group of minerals with compositions varying in a wide range $[11,12]$.

The chemical composition of fly ash from DTEK Prydniprovska TES is presented in Table 1. Table 2 shows the chemical composition of ash processing products.

Table 1. Chemical composition of fly ash.

\begin{tabular}{|l|c|c|c|c|c|c|c|c|c|c|c|}
\hline \multirow{2}{*}{ Product } & \multicolumn{10}{|c|}{ Content, \% of dry matter } \\
\cline { 2 - 12 } & $\mathrm{SiO}_{2}$ & $\mathrm{Fe}_{2} \mathrm{O}_{3}$ & $\mathrm{CaO}$ & $\mathrm{MgO}$ & $\mathrm{SO}_{3}$ & $\mathrm{Al}_{2} \mathrm{O}_{3}$ & $\mathrm{TiO}_{2}$ & $\mathrm{P}_{2} \mathrm{O}_{5}$ & $\mathrm{~K}_{2} \mathrm{O}$ & $\mathrm{Na}_{2} \mathrm{O}$ & $\mathrm{C}$ \\
\hline Fly ash & 49.66 & 12.32 & 2.18 & 1.27 & 0.44 & 12.87 & 0.53 & 0.90 & 3.10 & 0.67 & 12.00 \\
\hline
\end{tabular}

Table 2. Chemical composition of ash enrichment products.

\begin{tabular}{|c|c|c|c|c|c|c|c|c|c|c|c|c|c|}
\hline 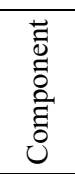 & $\mathrm{SiO}_{2}$ & $\mathrm{CaO}$ & $\mathrm{MgO}$ & $\mathrm{Al}_{2} \mathrm{O}_{3}$ & $\mathrm{Fe}_{2} \mathrm{O}_{3}$ & $\mathrm{ZnO}$ & $\mathrm{MnO}$ & $\mathrm{TiO}_{2}$ & $\mathrm{Na}_{2} \mathrm{O}$ & $\mathrm{K}_{2} \mathrm{O}$ & V & $\mathrm{S}_{\text {total }}$ & $\mathrm{C}$ \\
\hline 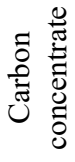 & 16.7 & 0.91 & 0.53 & 6.63 & 3.20 & 0.01 & 0.04 & 0.29 & 0.23 & 1.25 & 0.01 & 0.40 & 69.8 \\
\hline 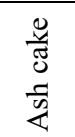 & 55.8 & 2.7 & 1.8 & 22.1 & 10.7 & 0.03 & 0.08 & 0.96 & 0.75 & 4.17 & 0.02 & 0.06 & 0.83 \\
\hline
\end{tabular}

Electron microscopic studies and X-ray diffraction analysis of the morphology of the ash phases and products of its enrichment have revealed the features of their surface microstructures [13].

Fig. 1 and 2 shows the general view of ash particles and ash concentrate of the Xproduct sample. The material consists of isolated aluminosilicate spheres, carbon particles and their intergrowths.

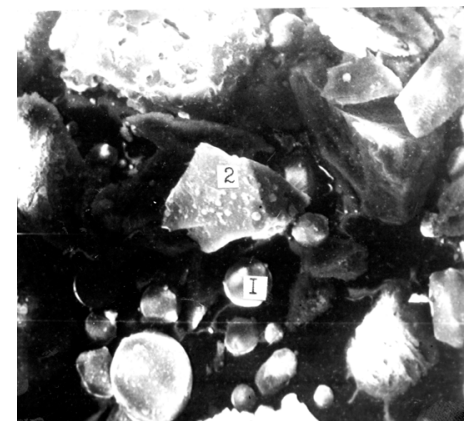

Fig. 1. General view of TPP ash particles (initial), magnification 517x: 1-spheres; $2-$ coal particles.

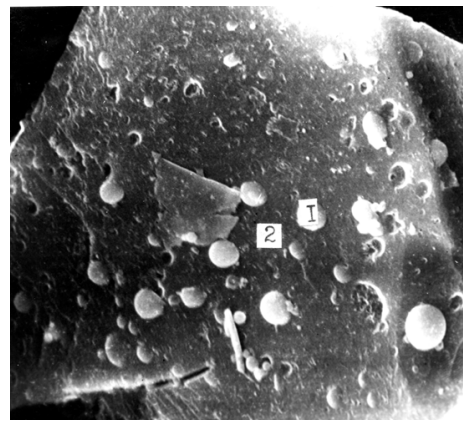

Fig. 2. General view of TPP ash concentrate, magnification 929x: 1 - spheres; 2 - coal particles.

Colonies of spheres located more deeply (in microcracks and microcavities) are not separated by this chemical activation, their separation is possible through mechanical action. After the treatment of the TPP ash concentrate with a $40 \%$ solution of $\mathrm{H}_{2} \mathrm{SO}_{4}$, the 
sample material predominantly consists of coal particles (Fig. 3). Treating the samples with acids results in a partial separation of the coal particles and shallowly embedded spheres from the concentrate surface, so that its surface acquires a cellular microstructure. After the treatment of the product with a $40 \% \mathrm{H}_{2} \mathrm{SO}_{4}$, the coal liberation occurred and the surface of the carbon particles has been cleared well of aluminosilicates (Fig. 3 and 4).

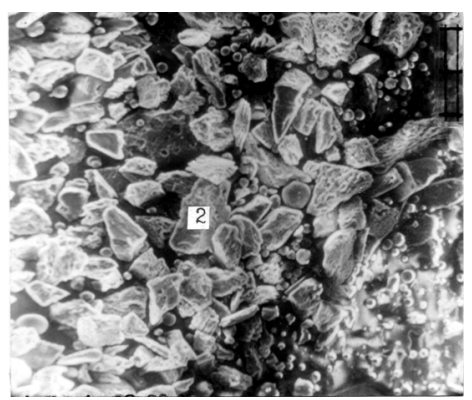

Fig. 3. General view of TPP ash particles (after treatment with $40 \% \quad \mathrm{H}_{2} \mathrm{SO}_{4}$ ), magnification 1305 x: 2 - coal particles.

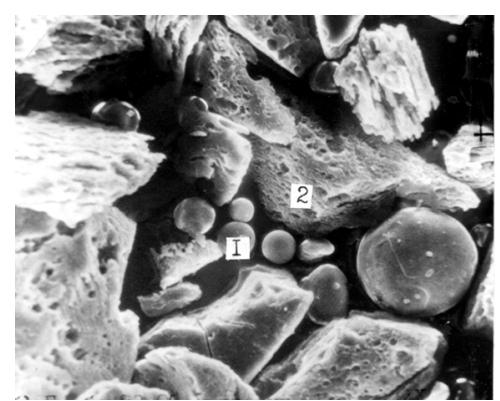

Fig. 4. Ash concentrate after treatment with $40 \% \mathrm{H}_{2} \mathrm{SO}_{4}$, magnification $842 \mathrm{x}: 1$ - spheres; 2 - coal particles.

The treatment of the X-product with a mixture of acids $(\mathrm{HCl}+\mathrm{H})(1: 3)$ almost completely cleaned up the material from the aluminosilicate component. There are single spheres. The surface of the coal particles is microporous, microcellular (Fig. 5 and 6).

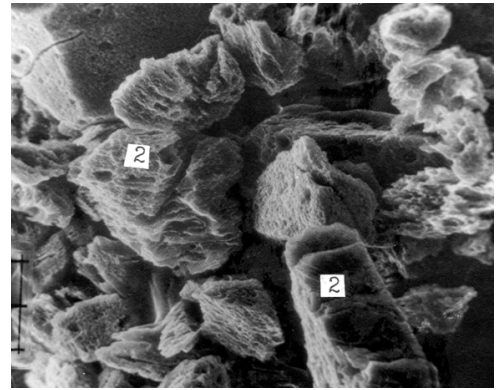

Fig. 5. General view of ash particles of TPP (after treatment with $\mathrm{HCl}+\mathrm{H}$ ), magnification 1305x: 2 - coal particles.

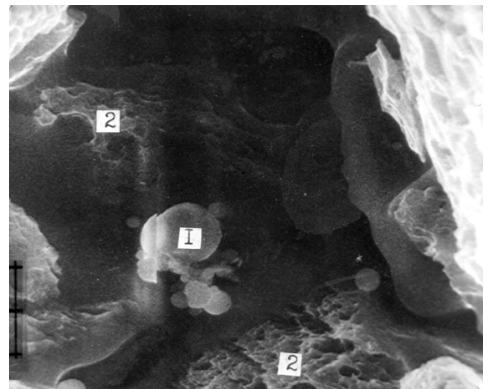

Fig. 6. General view of the carbon concentrate of TPP ashes, magnification 20x: 1 -spheres; 2 - coal particles.

The chemical composition of the mineral matter of the ash enrichment products practically coincides with the chemical composition of the waste, with the exception of the carbon content. An ash processing technique and a plant operating in conjugation with TPP will allow obtaining products of specified quality irrespective of the conditions of coal combustion at the TPP. This, on the one hand, excludes the building of new ash dumps at the TPP, and, on the other hand, allows the production of sorbents of oil products and heavy metals, heat-insulating coatings for steel casting, low-sulfur reductants, fuels, and raw materials for building materials [14].

The carbonaceous concentrate is also an effective sorbent of nonpolar and surfaceactive substances (surfactants), including petroleum products.

The resulting ash cake (mineral faction of ash) may have an ash content of $90-95 \%$. The decarburized aluminosilicates can find a variety of applications in the production of building materials, composites, in metallurgy and other industries.

The studies have confirmed the effectiveness of the use of enriched ash in the 
preparation of clay-ash claydite and brick, high-quality ash gravel, contact-condensate mixtures, as well as in the construction of road bases and coverings.

As a result, the coal concentrate may contain less than $20 \%$ of ash with a sulfur content of about $0.4 \%$. The sulfur content exceeds the European requirements. Such a coal product may be used as a reducing medium in metallurgical processes, agglomeration, etc. The calorific capacitance of the concentrate is about $6000 \mathrm{kcal} / \mathrm{kg}(25000 \mathrm{~kJ} / \mathrm{kg})$.

\section{Conclusions}

It has been discovered that in the case of high-temperature coal processing (within the range of $800-1300^{\circ} \mathrm{C}$ ), the sorbents of multipurpose use can be obtained.

It has been established that the most effective low-cost sorbents may be obtained under the TPP conditions with the controlled combustion of coal of certain grades.

Concrete obtained on the basis of alumo-silicate spheres separated from fly ash can be used for the production of light-weight concrete, external wall structures, small building blocks, and also in monolithic housing construction.

The use of preliminary shock-vibrating activation allows increasing the reactivity of aluminosilicates due to the formation of new effective bonds, that improves the physicalmechanical properties of binding materials based on them.

Authors express their gratitude to the private enterprise "Ukrpromtsert" for the help in providing experimental equipment during the work performance.

\section{References}

1. Petlovanyi, M.V., \& Medianyk, V.Y. (2018). Assessment of coal mine waste dumps development priority. Naukovyi Visnyk Natsionalnoho Hirnychoho Universytetu, (4), 28-35. https://doi.org/10.29202/nvngu/2018-4/3

2. Stavitskaya, S., Strelko, V., Nikipelova, Ye., Vikarchuk, V., Tsyba, N., Petrenko, T., \& Alekseenko N. (2009). Sintez i issledovanie novykh kombinirovannykh materialov na osnove modifitsirovannogo uglya i prirodnykh oksidov. Ukrainskiy himicheskiy zhurnal, 75(11), 29-34.

3. Dubinin, M. (1981). Adsorbtsiya parov vody i mikroporistaya struktura uglerodnykh adsorbentov. Izvestiya Akademii Nauk SSSR, (1), 9-21.

4. Belyaeva, O., Krasnova, T., \& Golubeva, N. (2017). Vliyanie usloviy predvaritel'nogo progreva aktivnykh ugley na adsorbtsiyu organicheskikh soedineniy iz vodnykh rastvorov. Sorbtsionnye $i$ khromatograficheskie protsessy, 17(6), 947-953.

5. Svetkina, O., Netiaga, O., \& Tarasova, H. (2015). Sorbents of purify mine waters. Theoretical and Practical Solutions of Mineral Resources Mining, 111-117. http://dx.doi.org/10.1201/b19901-77/

6. Adeeva, L., \& Borbat, V. (2009). Zola TETs - perspektivnoe syr'ye dlya promyishlennosti. Vestnik Omskogo Universiteta, (2), 141-151.

7. Ovchinnikov, R., \& Avakyan, A. (2013). Vliyanie razlichnykh metodov aktivatsii na svoystva kislykh zol TES kak aktivnoy dobavki v betony. Izvestiya vuzov, (6), 100-103.

8. Yeroshkina, N., Korovkin, M., \& Korovchenko, I. (2015). Ispolzovanie zoly TES v tekhnologii geopolimernykh stroitelnykh materialov. Molodoy uchenyy, (7), 117-120. https://moluch.ru/archive/87/17049/

9. Franchuk, V. (1975). Vibratsionnaya tekhnika v malykh proizvodstvakh. Heotekhnichna Mekhanika, (85), 290-296.

10. Petlovanyi, M.V., Lozynskyi, V.H., Saik, P.B., \& Sai, K.S. (2018). Modern experience of lowcoal seams underground mining in Ukraine. International Journal of Mining Science and 
Technology. Article in press. https://doi.org/10.1016/j.ijmst.2018.05.014

11. Svetkina, E. (2013) Intensifikatsiya protsessa obogascheniya pri vibroudarnoy aktivatsii mineralov. Naukovyi Visnyk Natsionalnoho Hirnychoho Universytetu, (2), 38-43.

12. Ishkov, V., \& Koziy, E. (2017). Distribution of toxic and potentially toxic elements in the coal of the layer c7h of the "Pavlogradskaya" mine of Pavlogradsko-Petropavlovskiy geological and industrial district. Visnyk of Taras Shevchenko National University of Kyiv, (79), 59-66. https://doi.org/10.17721/1728-2713.79.09

13. Svetkina, O., Netiaga, O., \& Tarasova, H. (2016). Physical and mechanical characteristics of binders based on TPP waste. Visnyk Natsionalnoho Tekhnichnoho Universytetu "Kharivskyi politekhnichnyi instytut", 22(1194), 177-182.

14. Rimkevich, V., Pushkin, A., \& Churushova, O. (2015). Complex processing of coal ash of TEC. Gornyy informatsionno-analiticheskiy byulleten', (6), 250-259. 